\title{
THE SPATIAL CONVERGENCE OR THE DIVERGENCE OF THE FEMINIZATION OF THE DEMOGRAPHIC OLD AGE IN POLAND?
}

\begin{abstract}
In the article based on information from the years 1991-2011 the following hypotheses were subjected to the verification: 1 . with time, we observe spatial standardizing of coefficient rate of the feminization of the demographic old age; 2 . the spatial image of the rate of the feminization of the demographic old age did not undergo the change over time; 3 . with time, the increases in the rate of the feminization of the demographic old age are more distinct in these areas, where its value was relatively high at the beginning of the analyzed period; 4 . different measures describing the spatial feminization of the demographic old age are leading to similar conclusions in the evaluation of its spatial convergence. Not all of the put forward theses were confirmed.
\end{abstract}

Keywords: age, ageing, feminization.

JEL: HS4_4.

\section{INTRODUCTION}

The evaluation of demographic old age uses multiple measures. They include e.g. ageing index or ageing ratio (Rosset 1967, Clarke 1965 Kowaleski 2011). These measures, however, show only a "sample" of the age structure of the population. Furthermore, the threshold of demographic old age is not clearly defined. Measures, which included information on the entire distribution were also proposed. These include life expectancy at the time of conception, where the threshold of demographic old age is defined by hypothetical minimum of older age determined by the number of years of life left (Sanderson and Scherbov 2007, after Abramowska-Kmon 2011). Synthetic measures that describe the distribution used percentiles (Kosinski 1967, Kowaleski 2011), concentration factor (d'Albis, Collard 2013), asymmetry factor (Cieslak 2004), the coefficient of relative gap of old age (Kot and Kurkiewicz 2004) and synthetic index of structure (Kurek 2008), the index of dissimilarity of structures (Rowland 1996), measures of the similarity of structures (Podogrodzka 2014).

\footnotetext{
*Warsaw School of Economics, mpodog@sgh.waw.pl
} 
Since all these measures show the advancement of demographic old age in statistical terms, it was suggested that its dynamics should be evaluated by including information about the relationship between their point-values (Dlugosz 1998, Kurek 2008, Kowaleski 2011), the quotient between the average annual rate of population growth in the elderly age and the average annual growth rate of the total population (Kondrat 1972, Frątczak 2002), regression function (Podogrodzka 2015) or the aggregate index of structure (Wieniecki 1981).

Polish literature includes a lot of studies devoted to the issues of demographic old age in spatial terms. They include, e.g. the papers of Dlugosz 1997, Potrykowska 2003, Kowaleski and Szukalski, 2004, Kowaleski and Szukalski 2006, Kurek 2008, Kowaleski 2011, Podogrodzka 2014, Podogrodzka 2015. These studies mainly used indexes of the structure, and indexes of dynamics to describe their changes in value over time. These analyses related to the total population and the population living in urban and rural areas. However, there are no studies to show differences in the intensity and dynamics of demographic aging between the sexes.

The study of aging of population can be either static or dynamic. In the first case, the degree of severity in a given area within a given point in time is analyzed. In the second case, the intensity of its changes over time is subjected to analysis. In both cases the aim is to detect certain regularities in spatial terms, which are designed to isolate groups of individuals (typology, regionalization), which are characterized by similar properties.

The aim of this article is to show the spatial differences in the assessment of demographic old age of women and men and their changes over time. Considerations are conducted for the years 1991-2011. The description will allow to verify the following hypotheses: 1) with time, we observe the spatial unification of the values of rate of feminization of demographic old age; 2) the spatial image of the rate of feminization of demographic old age did not change over time; 3 ) with time, the increases in the feminization rate of demographic old age are more pronounced in those areas where its value was relatively high at the beginning of the studied period; 4) various measures describing spatial feminization of demographic old age lead to similar conclusions in its assessment of spatial convergence.

The considerations adopted province as the object of comparison, while in the description of demographic old age it was youth rate, i.e. the percentage of people aged under 19 in the total population. The lower the value of this measure, the older was the age structure of the population; the index of old age was counted - once - as a percentage of people aged 65 years and older, and - for the second time - as a percentage of people aged 75 years and older. The higher the value of this measure, the older was the age structure of the population; old age index was calculated as the ratio of old age - once - share of 
persons aged 65 years and older, and - for the second time- share of persons aged 75 years and older to the share of persons aged 0-19 years. The higher the value of this measure, the larger was the burden of the young with the elderly the average life expectancy at the time of conception. The higher the value of this measure the older is age structure of the population. Each of the presented measures of demographic aging included the definition of the feminization rate or its inverse ${ }^{1}$. If the measure takes:

- a value of 1 (or 100) - the percentage of women in that age group is the same as the percentage of men in the same age group (no feminization);

- a value higher than 1 - the share of women in that age group is higher than the share of men in the same age group (increase of feminization);

- a value lower than 1 - the share of women in that age group is lower than the percentage of men in the same age group (decrease of feminization).

The literature distinguishes three types of convergence. Measurements of the dispersion (coefficient of variation, the area of variation) allow to determine the degree of decreasing the spatial disparity of the variable over time, and thus the convergence sigma type $(\mathrm{H} 1)^{2}$.

On the other hand, convergence gamma examines the stability of distribution of variable over time $(\mathrm{H} 2)$. A rank correlation coefficient is the most commonly used measure in this case. Convergence beta examines the extent to which the level of the variable affects the rate of its value changes over time (H3). For this purpose, the correlation between the value of a variable at the beginning of the period and the measure of dynamics is determined. The assessment of the dynamics of these measures used a linear function of the trend $^{3}$.

The delimitation of the provinces similar in assessing the degree of feminization of demographic old age involved the use of one of the taxonomic methods, i.e. the relationship between the cross arithmetic mean, and $\mathrm{k}=1.2$ the number of cross standard deviations (Pociecha et al., 1988, Młodak 2006). In this way, the six classes of similar provinces were created. The information about the participation of the population by five-year age groups at the end of the year come from Eurostat web pages, and the calculation was performed using Statistica.

${ }^{1}$ Feminization rate is the ratio of the percentage of women in a specific age group to the percentage of men in the same age group. Masculinization rate is the inverse relationship.

${ }^{2}$ The literature often presents the use of standard deviation to identify the types of sigma convergence. However, this is non-standard measure, which means it should not be used for comparisons across different communities and their changes over time.

${ }^{3}$ A linear trend function has been determined from the information on the day of 31.12. each year of the period. 


\section{MEASURES OF DEMOGRAPHIC OLD AGE}

\subsection{Index of youth}

In the years 1991-2011 in all provinces, we observe the advantage of the percentage of men aged 0-19 years in relation to the percentage of women, which also grows in time. Therefore, we can see a clear decrease in feminization in this age group. In addition, the spatial differences in values of feminization rate (k. Sigma) decrease over time, i.e. these units are becoming increasingly similar because of the value of the measurement (Figure 1).

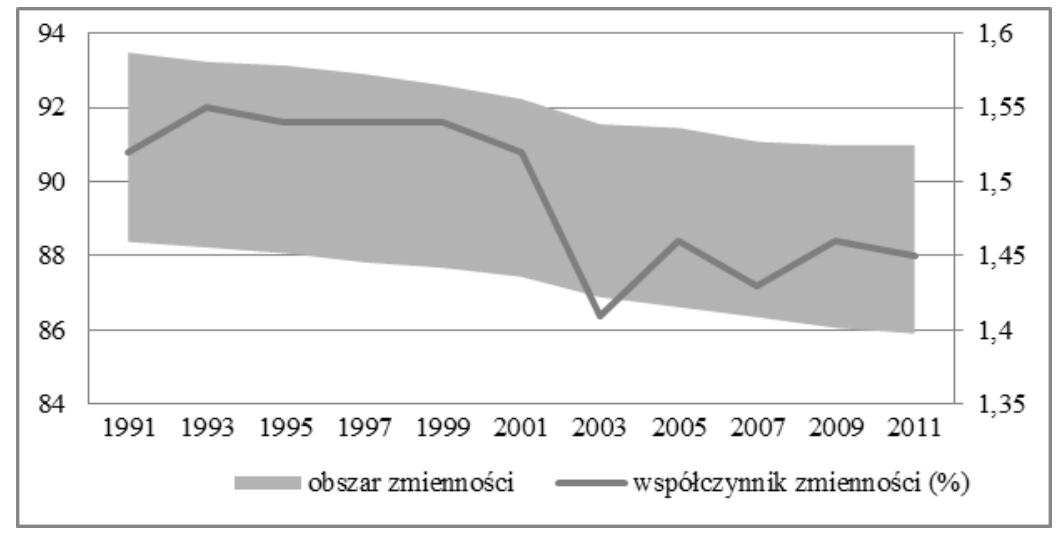

Figure 1. Cross-sectional measures of dispersion of coefficient of the feminization for the youth index in Poland in years 1991-2011

Source: own calculations.

Spatial image of feminization rate designated for the index of youth was not stable over time (k.gamma). Throughout the period, the provinces characterized by the lowest values were located mainly in the central part of the country, while the highest values, at the beginning of the 90s were recorded in northern Poland, although only in the north-east and also in the south-east in the following decades. This means, that over time, the advantage of men aged 0-19 years compared to women of the same age has increased mainly in the eastern Poland. We did not notice the a clear relationship between the intensity of change in this measure over time and its value at the beginning of the studied period (no k.beta) (Figure 2). 


\begin{tabular}{|c|c|c|c|c|}
\hline & Groups & 2011 & & \\
\hline
\end{tabular}

Figure 2. Rate of feminization for the index of youth by provinces in Poland in the years 1991, 2001 and 2011

Note: the darker the color, the higher the value of the measure.

Source: own elaboration.

\subsection{Index of old age}

In the analyzed period, the feminization designated for the percentage of people aged 65 and older in all provinces took higher and higher values, and that means deepening of the process of feminization in this age group. Simultaneously, different spatial intensity of these changes caused that, over time, these units have become somewhat more similar (k.sigma) (Figure 3).

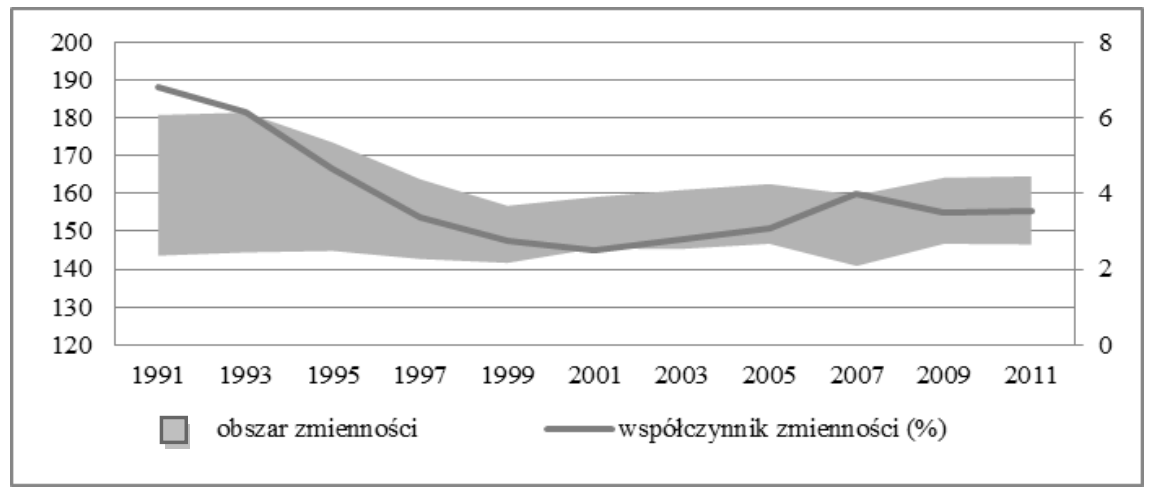

Figure 3. Cross-section measures of dispersion of rate of feminization of index of old age in Poland in the years 1991-2011

Source: own calculations.

The spatial image of the feminization rate calculated for persons aged 65 years and more clearly changed over time (k.gamma). In the early 90s, the regions characterized by the lowest values were located in the north-east and south-west parts of Poland, but a decade later they were already located in the central and north-east parts of the country. The next decade brings a new 
situation. These provinces are located mainly in the southern part of Poland. While the highest differences between the genders initially occurred in the south, and in subsequent years already in the western and north-east parts. However, it cannot be concluded that the intensity of changes over time of feminization rate of old age index was dependent on its value from the beginning of the period (no k.beta) (Figure 4).

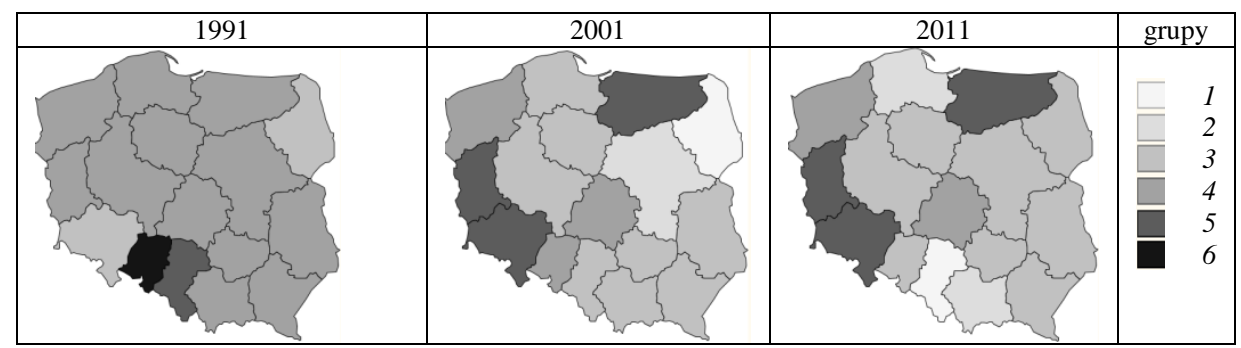

Figure 4. The rate of feminization of old age index in Poland in the years 1991, 2001 and 2011 Note: the darker the color, the higher the value of the measure.

Source: own calculations.

The feminization rate of old age index calculated as the proportion of people aged 75 years in the total population leads to similar conclusions as those outlined above. With time, in all provinces the process of feminization is deepening, and simultaneously, the differences in the value between the spatial units are decreasing (k.sigma). However, here these changes were more pronounced than those previously observed (Figure 5).

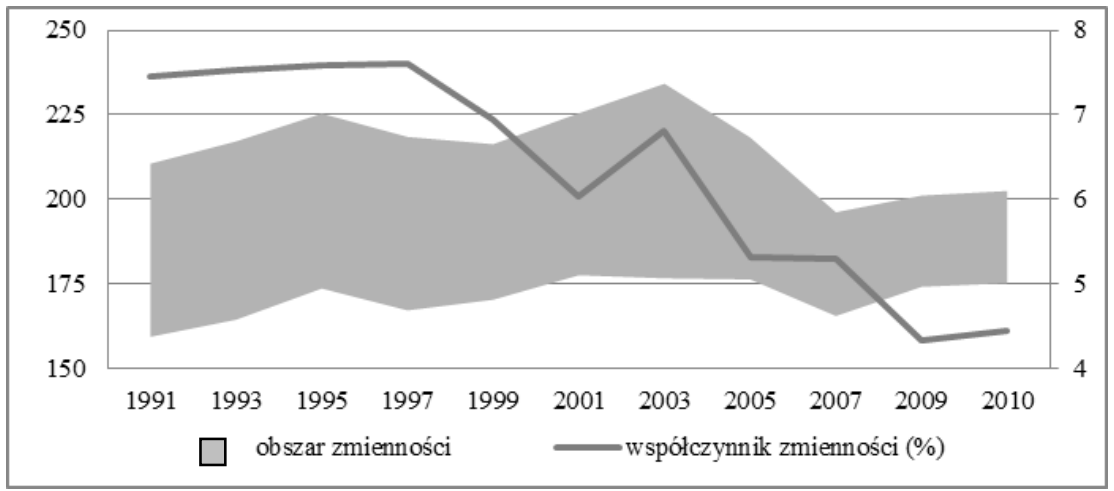

Figure 5. Cross-section measures of dispersion of feminization for old age index in Poland in the years 1991-2011

Source: own calculations. 
Spatial image of feminization rate was not stable over time (k.gamma). At the beginning of the period, most provinces characterized by high values of this measure were located mainly in the southern part of Poland. In the following decades, this situation initially concerned the central-northern and centralsouthern part of the country and later it was associated with the western part. In the case of the lowest values, it permanently concerned the provinces in the central and eastern Poland. At the same time, the spatial intensity of changes of this value did not depend on its value at the beginning of the period (no k.beta) (Figure 6). It should also be noted that the spatial image of feminization rate calculated for the percentage of people aged 75 years and over, was different from that observed for the percentage of people aged 65 and more.

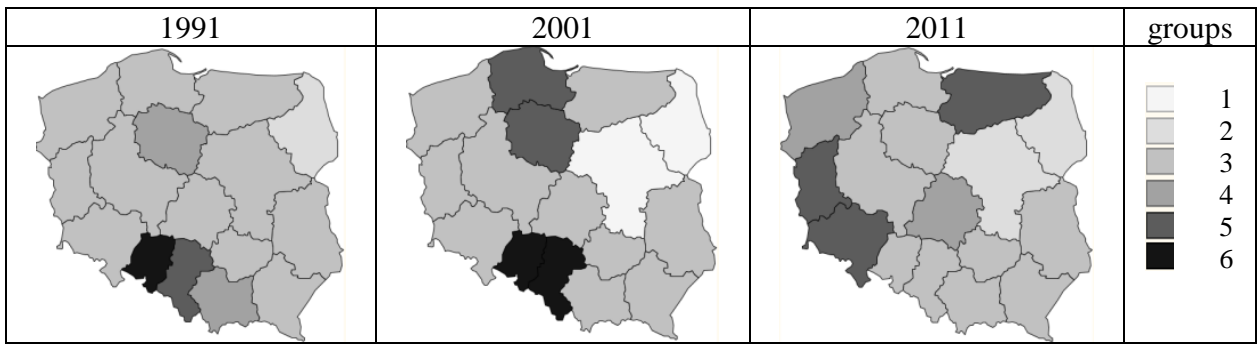

Figure 6. The feminization rate for old age index in Poland in the years 1991, 2001 and 2011

Note: the darker the color, the higher the value of this measure.

Source: own calculations.

\subsection{Old age index}

In the years 1991-2011 in all provinces, the feminization rate designated for the relationship of percentage of people aged 65 years and older and the percentage of people aged under 19 received higher and higher values. Therefore, we observe a clear deepening of disparities in relation grandmother / granddaughter and grandfather / grandson reflecting the feminization of generation replacement. As the intensity of these changes was not uniform in the provinces, in the course of time we record a slight decline in these spatial differences (k.sigma). The tested units somewhat became similar to each other (Figure 7).

The spatial image of the measure was not stable over time (k.gamma). Initially, the regions characterized by the highest values were located in centralsouth parts of the country, but after the next two decades, also in the western part. While those spatial units, which were characterized by the lowest values were located in different parts of Poland. At the same time, the dynamics of change of rate of feminization did not depend on its intensity at the beginning of the period (no k.beta) (Figure 8). 


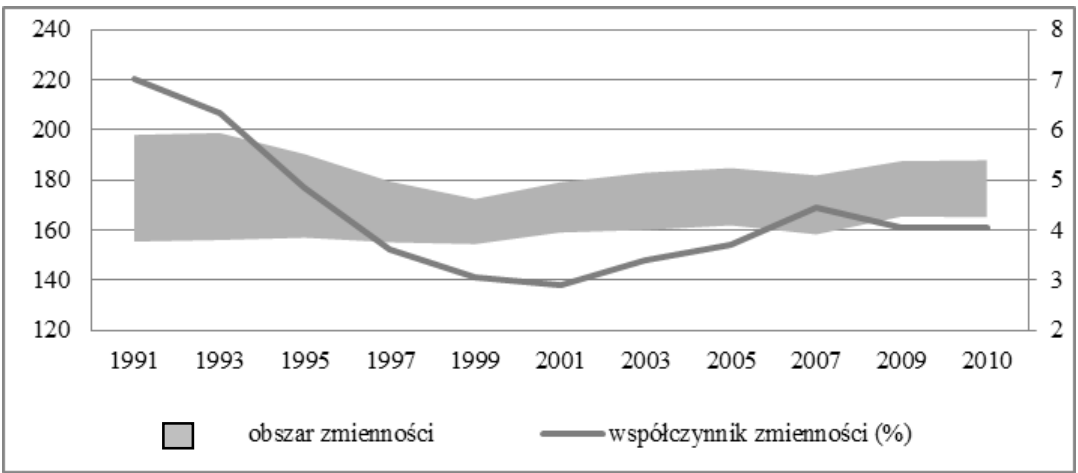

Figure 7. Cross-section measures of dispersion of rate of feminization of old age index in Poland in the years 1991-2011

Source: own calculations.

\begin{tabular}{|c|c|c|c|c|}
\hline & 2001 & groups \\
\hline
\end{tabular}

Figure 8. The feminization rate of old age index in Poland in the years 1991, 2001 and 2011

Note: the darker the color, the higher the value of this measure.

Source: own elaboration.

Similar changes as above were observed for the rate of feminization calculated as the ratio of the share of persons aged 75 years and older and the share of people aged below 19 years of age. Also in this case, in all the provinces we noticed an increase in the feminization and spatial unification of its value, but here these changes were more pronounced (k.sigma) (Figure 9).

The spatial distribution of this measure also changed over time (k.gamma). In the early $90 \mathrm{~s}$, the provinces characterized by its high values were located in central and southern parts of the country. In the next decade, this situation has slightly changed, although it still concerned the south, but also the centralnorthern part, and ten years later parts of northern and eastern Poland. The lowest values of feminization rate included, invariably in time, part of the eastern Poland. There was no clear relationship between the intensity of changes of its value over time and its intensity at the beginning of the studied period (no k.beta) (Figure 10). 


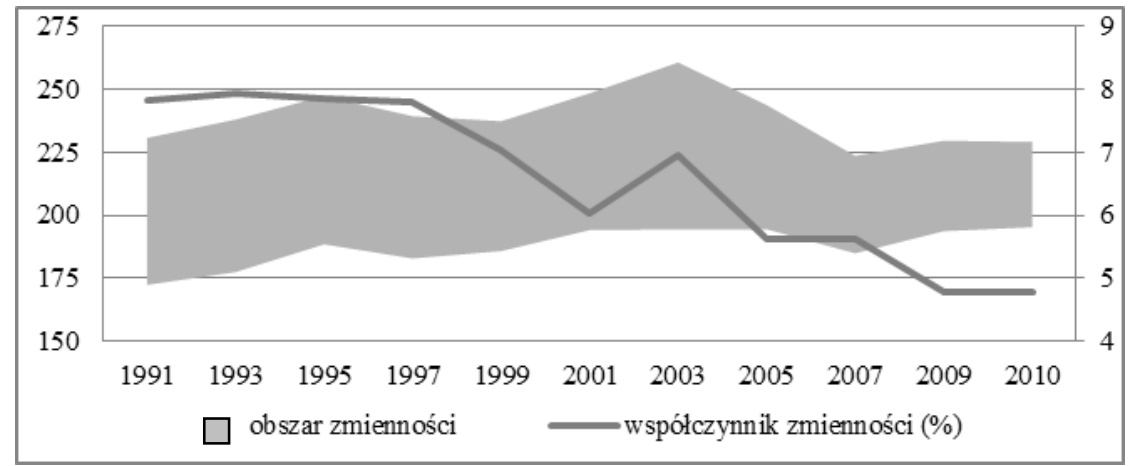

Figure 9. Cross-section measures of feminization rate for old age index in Poland in the years 1991-2011

Source: own calculations.

\begin{tabular}{|l|l|l|l|}
\hline & 2001 & groups \\
\hline
\end{tabular}

Figure 10. Feminization rate of old age index in Poland in the years 1991, 2001 and 2011 Note: the darker the color, the higher the value of the measure.

Source: own elaboration.

\subsection{Further life expectancy}

With time, all provinces showed an increase in value for the relationship of further average life expectancy at the time of conception, determined separately for women and for men. This means that the process of feminization deepened in these spatial units and, at the same time, the differences between them increased (no k.sigma) (Figure 11).

Also in this case, the spatial image of the measure changed with time. Initially, part of the southern Poland was characterized by the lowest values, but two decades later this concerned the north-western part. Its highest value at the beginning of the 90s related to provinces in various parts of the country, and then those that were in the north-east, and after the next decade the southern part of the country (k.gamma). In these areas of Poland, where at the beginning of the period values feminization were already relatively high, their value increases over time were higher than in places where these values were low (k.beta) (Figure 12). 


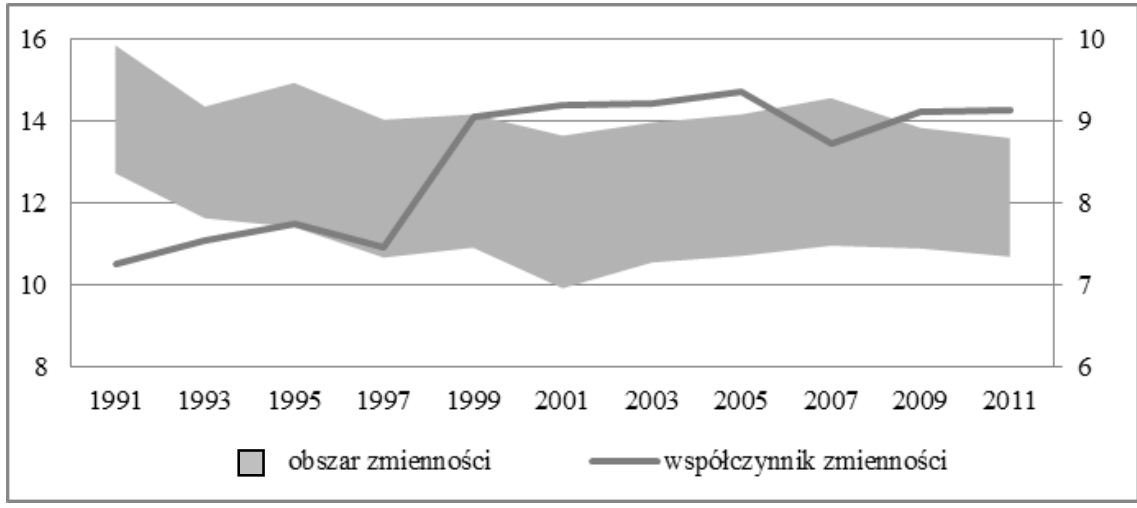

Figure 11. Cross-section measures of dispersion of feminization rate of the average life expectancy at the time of conception in Poland in the years 1991-2011

Source: own calculations.

\begin{tabular}{|c|c|c|c|}
\hline & groups \\
\hline
\end{tabular}

Fig. 12. Rate of feminization for the average life expectancy at the time of conception in Poland in the years 1991, 2001 and 2011

Note: the darker the color, the higher the value of the measure.

Source: own elaboration.

\section{CONCLUSION}

The intensity and dynamics of population aging depend on three demographic processes, i.e. fertility, mortality and migration (migration movement of the population). While in the first case it can be clearly stated that the decline in birth rates is conducive to this phenomenon, the other two cases show no such unambiguity. A similar situation exists in the case of selecting measures of assessing the demographic age. The most popular are those which show a relationship between two groups of age. Their dynamics is assessed primarily by the relationship between the point-values of these indexes. Polish literature includes a lot of studies devoted to the issues of spatial differentiation 
of demographic aging, but no assessment of the similarity of the results depending on the measure is available. These considerations did not show the differences in the extent and dynamics of this process between the sexes. This article was intended to fill this gap. The delimitation of areas similar as for the degree of feminization of demographic old age was carried out using a variety of its measures, and the analysis of their changes over time. Considerations were carried out by provinces for the years 1991-2011. They allowed for the following conclusions:

1) with time, spatial convergence sigma was observed, i.e. unifying the values of feminization rate for almost all measures describing demographic old age. The exception is the average life expectancy at the moment of conception;

2) with time, spatial image of rate of feminization of demographic old age changed ( gamma convergence);

3 ) with time, increases in the feminization rate of the average life expectancy were more pronounced in those areas where its value was already relatively high at the beginning of the period (beta convergence). No such relation was observed in the case of other measures of old age.

The discrepancies in the obtained results are based on the construction of the presented measures. Some include the entire age structure of the population, while others take into account only part of it. This is the case where the structure of the population is not stabilized. Therefore, it seems that the selection of the type of measure for the static evaluation of demographic old age does not matter, but this factor gains a particular importance when we run the considerations in time.

\section{BIBLIOGRAPHY}

Abramowska-Kmon A. (2011), O nowych miarach zaawansowania procesu starzenia się ludności”, „Studia demograficzne”, nr 1(159), s. 3-33.

Clarke J.I. (1965), Population geography, Pergamon Press, Oxford, p. 164.

Cieślak M. (2004), Pomiar procesu starzenia się ludności, „Studia Demograficzne”, nr 2(146), s. $3-16$.

d'Albis H., Collard F. (2013), Age groups and the measure of population aging, "Demographic Research", nr 29, p. 617-640.

Długosz, Z. (1997), Stan i dynamika starzenia się ludności Polski, „Czasopismo Geograficzne”, 68(2), s. 227-232.

Długosz Z. (1998), Próba określenia zmian starości demograficznej Polski w ujęciu przestrzennym, „Wiadomości Statystyczne”, nr 3, s. 15-25.

Frątczak E. (2002), Proces starzenia się ludności Polski, „Studia Demograficzne”, nr 2 (142), s. 3-28

Kot S.M., Kurkiewicz J. (2004), The new measures of the population ageing, „Studia Demograficzne", nr 2/146, s. 17-29.

Kondrat W. (1972), Zmiany w strukturze ludności wedtug ptci i wieku w latach 1950, 1960, 1970, „Studia i Prace Statystyczne”, nr 40.

Kosiński L. (1967), Geografia ludności, PWN, Warszawa.

Kowaleski J. (2011), Przestrzenne zróżnicowanie starzenia się ludności Polski. Przyczyny. Etapy. Następstwa, Wydawnictwo Uniwersytetu Łódzkiego, Łódź. 
Kowaleski J.T., Szukalski P. (red.) (2004), Nasze starzejące się spoleczeństwo. Nadzieje i zagrożenia, Wydawnictwo Uniwersytetu Łódzkiego, Łódź.

Kowaleski J.T., Szukalski P. (red.) (2006), Starość i starzenie się jako doświadczenie jednostek i zbiorowości ludzkich, Wydawnictwo Uniwersytetu Łódzkiego, Łódź.

Kurek S. (2008), Typologia starzenia się ludności Polski w ujęciu przestrzennym, Wyd. Akademia Pedagogiczna w Krakowie, Prace Monograficzne nr 497, Kraków.

Młodak M. (2006), Analiza taksonomiczna w statystyce regionalnej, Difin, Warszawa.

Pociecha J., Podolec B., Sokołowski A., Zając K. (1988), Metody taksonomiczne w badaniach społeczno-ekonomicznych, PWN, Warszawa.

Podogrodzka M. (2014), Przestrzenne zróżnicowanie ludności wedlug wieku w Polsce w 1991-2010, [w:] A. Rączaszek, W. Koczur (red.) Polityka społeczna wobec przemian demograficznych. Studia Ekonomiczne nr 167, Wyd. UE w Katowicach, Katowice, s. 62-76.

Podogrodzka M. (2015), O przestrzennym zróżnicowaniu struktur wieku ludności w Polsce, 19912011, Kwartalnik Kolegium Ekonomiczno-Społecznego. Studia i Prace, Wyd. SGH, Warszawa, nr 1, s. 35-58.

Potrykowska A. (20030, Przestrzenne zróżnicowanie procesu starzenia się ludności i migracji osób w starszym wieku w Polsce, „Przegląd Geograficzny”, nr 1, s. 41-59.

Rosset E. (1967), Ludzie starzy. Studium demograficzne, PWE, Warszawa.

Rowland D.T., 1996, Population momentum as a measure of aging, "European Journal of Population", 12, s. 41-61.

Sanderson W., Scherbov S. (2007), A new perspective on population ageing, "Demographic Research", nr 16(2), s. 27-58.

Wieniecki I.G. (1981), Starzenie się ludności i metody statystyczne jego pomiaru, [w:] Metody statystyczne w demografii, PWN, Warszawa, s. 76-90.

http://epp.eurostat.ec.europa.eu/portal/page/portal/population/data/database [dostęp 12.03.2014]

Matgorzata Podogrodzka

\section{PRZESTRZENNA KONWERGENCJA CZY DYWERGENCJA FEMINIZACJI STAROŚCI DEMOGRAFICZNEJ W POLSCE?}

Streszczenie. W artykule na podstawie informacji z lat 1991-2011 weryfikacji poddano następujące hipotezy: 1. z czasem odnotowujemy przestrzenne ujednolicanie się wartości współczynnika feminizacji starości demograficznej; 2. przestrzenny obraz współczynnika feminizacji starości demograficznej nie uległ zmianie w czasie; 3. z czasem przyrosty współczynnika feminizacji starości demograficznej są wyraźniejsze na tych obszarach, gdzie jego wartość była relatywnie wysoka na początku badanego okresu; 4. różne miary opisujące przestrzenną feminizację starości demograficznej prowadzą do podobnych wniosków w ocenie jej przestrzennej konwergencji. Nie wszystkie z postawionych tez zostały potwierdzone.

Słowa kluczowe: starość, struktura ludności, feminizacja.

JEL: HS4_4. 